\title{
MicroRNA-424/503 cluster members regulate bovine granulosa cell proliferation and cell cycle progression by targeting SMAD7 gene through activin signalling pathway
}

Hari Om Pande ${ }^{1}$, Dawit Tesfaye ${ }^{1,3}$, Michael Hoelker $^{1,2,3}$, Samuel Gebremedhn ${ }^{1}$, Eva Held ${ }^{1,2}$, Christiane Neuhoff ${ }^{1}$, Ernst Tholen ${ }^{1}$, Karl Schellander ${ }^{1,3}$ and Dessie Salilew Wondim ${ }^{1 *}$

\begin{abstract}
Background: The granulosa cells are indispensable for follicular development and its function is orchestrated by several genes, which in turn posttranscriptionally regulated by microRNAs (miRNA). In our previous study, the miRRNA-424/503 cluster was found to be highly abundant in bovine granulosa cells (bGCs) of preovulatory dominant follicle compared to subordinate counterpart at day 19 of the bovine estrous cycle. Other study also indicated the involvement of miR-424/ 503 cluster in tumour cell resistance to apoptosis suggesting this miRNA cluster may involve in cell survival. However, the role of miR-424/503 cluster in granulosa cell function remains elusive Therefore, this study aimed to investigate the role of miRNA-424/503 cluster in bGCs function using microRNA gain- and loss-of-function approaches.

Results: The role of miR-424/503 cluster members in granulosa cell function was investigated by overexpressing or inhibiting its activity in vitro cultured granulosa cells using miR-424/503 mimic or inhibitor, respectively. Luciferase reporter assay showed that SMAD7 and ACVR2A are the direct targets of the miRNA-424/503 cluster members. In line with this, overexpression of miRNA-424/503 cluster members using its mimic and inhibition of its activity by its inhibitor reduced and increased, respectively the expression of SMAD7 and ACVR2A. Furthermore, flow cytometric analysis indicated that overexpression of miRNA-424/503 cluster members enhanced bGCs proliferation by promoting G1- to S- phase cell cycle transition. Modulation of miRNA-424/503 cluster members tended to increase phosphorylation of SMAD2/3 in the Activin signalling pathway. Moreover, sequence specific knockdown of SMAD7, the target gene of miRNA-424/503 cluster members, using small interfering RNA also revealed similar phenotypic and molecular alterations observed when miRNA-424/503 cluster members were overexpressed. Similarly, to get more insight about the role of miRNA-424/503 cluster members in activin signalling pathway, granulosa cells were treated with activin A. Activin A treatment increased cell proliferation and downregulation of both miRNA-424/503 members and its target gene, indicated the presence of negative feedback loop between activin A and the expression of miRNA-424/503.
\end{abstract}

Conclusion: This study suggests that the miRNA-424/503 cluster members are involved in regulating bovine granulosa cell proliferation and cell cycle progression. Further, miRNA-424/503 cluster members target the SMAD7 and ACVR2A genes which are involved in the activin signalling pathway.

Keywords: miR-424/503 cluster members, Granulosa cells, SMAD7, ACVR2A, Activin a

\footnotetext{
* Correspondence: dsal@itw.uni-bonn.de

'Department of Animal Breeding and Husbandry, Institute of Animal Science,

University of Bonn, Endenicher Allee 15, 53115 Bonn, Germany

Full list of author information is available at the end of the article
}

(c) The Author(s). 2018 Open Access This article is distributed under the terms of the Creative Commons Attribution 4.0 International License (http://creativecommons.org/licenses/by/4.0/), which permits unrestricted use, distribution, and reproduction in any medium, provided you give appropriate credit to the original author(s) and the source, provide a link to the Creative Commons license, and indicate if changes were made. The Creative Commons Public Domain Dedication waiver (http://creativecommons.org/publicdomain/zero/1.0/) applies to the data made available in this article, unless otherwise stated. 


\section{Background}

The mammalian follicle, consisting of an oocyte surrounded by granulosa and theca cells, represents the basic functional unit of the ovary [1]. The growth of the obligatory gonadotropin-dependent follicle, which is a complex but nevertheless well-coordinated process, occurs in a wave-like fashion, with two to three waves per oestrous cycle [2] followed by ovulation or atresia. Among the follicular cells, granulosa cells are critically indispensable for the growth and maturation of follicles, and they undergo a series of morphological and functional changes [3]. The primordial follicle, holding an arrested oocyte at diplotene stage, is enclosed by a single flattened layer of somatic granulosa cells (GCs) [4]. Further, the sequential, well-controlled transformation from the primordial to antral follicle stage is the result of the differentiation and proliferation of GCs that provide essential and vital inputs in the form of steroid hormones, cytokines, and paracrine and autocrine factors during the process of follicular development [5-7], which is tightly regulated by array of genes $[3,5,6,8,9]$ that may in turn fine-tuned by microRNAs $[10,11]$.

To better understand the genetic regulation of granulosa cell function and their role in follicular development, several transcriptome profiling studies have been conducted to examine the expression patterns of genes in bovine granulosa cells (bGCs) [8] at different phases of antral follicle growth [9]. Accordingly, several genes involved in steroidogenesis (CYP17A1, CYP11A1, $H S D 3 B 1, \quad S T A R)$, cell proliferation/the cell cycle (CCND2, PCNA), gonadotropin receptors (LHCGR, $F S H R$ ) and growth factors (GDF9, BMP2, Activins, IGF1, $I G F 2$ ) have been found to be altered in granulosa cells depending on the size and stage of follicular development $[3,12-16]$.

Granulosa cell proliferation and differentiation have been reported as important cellular activity within dominant follicle in the late phase of estrous cycle $[17,18]$. STAR is a key molecule in steroidogenesis and is a marker of granulosa cell differentiation [19].

These molecular cues, which are responsible for follicular development, are under the control of several epigenetic mechanisms, including microRNAs (miRNAs). These small noncoding RNAs, $\sim 20-22$ nucleotides in length, are epigenetic regulators that control gene expression post-transcriptionally by targeting the 3 '-UTR in a sequence-specific manner leading to mRNA degradation or translation inhibition $[10,11]$.

MicroRNAs play crucial roles in almost all biological functions, including cell proliferation, differentiation, and apoptosis $[12,13]$, and disturb function of miRNAs are associated with various diseases such as cancer [20]. Since the discovery of first miRNA (Lin-4) in 1993 [10, 21], a continuing major challenge has been deciphering the functional aspects of miRNAs in bio-physiology, including mammalian reproduction. Previous evidences support the involvement of miRNAs in follicular growth and development through the regulation of granulosa cell proliferation, differentiation, apoptosis and steroidogenesis [22-28]. However, limited numbers of studies have validated the role of miRNAs in bovine follicular development [12, 13, 23].

Previously, we have reported the expression pattern of miRNAs in bovine granulosa cells of subordinate and dominant follicles during the early luteal phase (day 3 and day 7) [29] and late follicular phase (day 19) [23] of the bovine oestrous cycle and their possible association with follicular recruitment, selection and dominance. In the latter study, of the 64 total differentially expressed miRNAs, the miR-424/503 cluster was significantly enriched in the granulosa cells of preovulatory dominant follicles. Inline to this, recent studies have demonstrated that the miR-424/503 cluster enhances tumour cell resistance to apoptosis [30], coordinates the remodelling of the epithelium in the involution of mammary gland [31], and reverses chemo-resistance via T-cell immune response activation by blocking the PD-L1 immune checkpoint [32]. Nonetheless, the involvement of the miR-424/503 cluster in reproductive functions remains elusive. With in-silico analysis mothers against decapentaplegic homolog 7 (SMAD7) and activin receptor type $2 \mathrm{~A}(A C V R 2 A)$ were identified as target genes of miR$424 / 503$, which are associated with the activin signalling pathway of the TGF- $\beta$ superfamily members and a known key regulator of follicle development in mammals [33]. In the present study, we demonstrated that miR424/503 cluster epigenetically regulates bovine granulosa cell function by targeting SMAD7, and through fine tuning of the activin signalling pathway.

\section{Methods \\ MicroRNA target gene prediction}

The mature sequences of miR-424-5p (miR-424) and miR-503-5p (miR-503) were obtained from the miRBase (http://www.mirbase.org/) database. We performed an in silico target prediction for potential putative targets using the miRWalk database (http://zmf.umm.uni-heidelberg.de/apps/zmf/mirwalk/). The miRNA-mRNA binding site prediction in bovine sequences was performed using TargetScan 6.2 [34]. Target gene predictions were considered according to rank based on the predicted efficacy or targeting as calculated using 'cumulative weighted context++ scores' of the sites [34] and probability of conserved targeting $\left(\mathrm{P}_{\mathrm{CT}}\right)$ [35]. Accordingly, among several genes, the SMAD7 [36] and $A C V R 2 A$ genes, which are ubiquitously expressed in the ovarian follicle and important in reproductive performance [37], were selected for functional analysis. The secondary structure of miR-424 and miR-503 was predicted 
by RNAhybrid (http://bibiserv.techfak.uni-bielefeld.de/ rnahybrid).

\section{Bovine granulosa cell culture and transfection}

Bovine ovaries as sources of bGCs were collected from a local slaughterhouse. Ovaries were processed to obtain follicular fluid and isolation of granulosa cells as described previously [12]. Further, a total of $2.0-2.5 \times 10^{5}$ bGCs per well were seeded into CytoOne ${ }^{\circ}$ 24-well plate (Starlab International GmbH, Germany) in the F12+ culture media. The bGCs were cultured in $37{ }^{\circ} \mathrm{C}$ with $5 \%$ $\mathrm{CO}_{2}$ in humidified environment. The bGCs were incubated for $48 \mathrm{~h}$ to attach and pre-confluent $(60-70 \%)$ for treatment or transfection purpose. In the culture medium FSH, IGF1 or other factors were not added to avoid its effect on bovine granulosa cell proliferation. In some experiments cells were cultured in the presence of Recombinant Human/Mouse/Rat Activin A (R\&D Systems, MN, USA).

The chemically synthesized miRNA-424-5p mimic and inhibitor, miR-503-5p mimic and inhibitor, and the corresponding negative controls (NC) were used to transfect (Qiagen $\mathrm{GmbH}$, Germany) bGCs. The miRNAs and/or plasmids were diluted in Opti-MEM I reducedserum medium (Invitrogen). Sub-confluent cultured bGCs (70-80\% confluent) were co-transfected with $500 \mathrm{ng}$ of the wild-type or mutant-construct plasmid and $50 \mathrm{nM}$ individual microRNA mimic or mimic control. For miR-424/503 gain- and loss-of-function analysis, $50 \mathrm{nM}$ individual microRNA mimic, inhibitor or corresponding negative controls were co-transfected to sub-confluent cultured bGCs. The transfection was performed using Lipofectamine 2000 transfection reagent (Life Technologies, Germany).

\section{Plasmid construction and luciferase assay}

To validate whether the $S M A D 7$ and $A C V R 2 A$ gene are real targets of the miR-424/503 cluster, fragments of the 3'-UTR of SMAD7 or 3'-UTR of ACVR2A containing the binding sites for miR-424-5p (miR-424) and miR503-5p (miR-503) (wild type) or with mutations in the seed sequences of miR-424/503 (mutant type) (Fig. 1) were cloned and inserted between the $S a c \mathrm{I}$ and $\mathrm{XhoI}$ restriction sites of the pmirGLO Dual-Luciferase miRNA Target Expression Vector (Promega Corporation, USA). The cDNA from ovarian bGCs was used to amplify the predicted miRNA-mRNA binding site in the $3^{\prime}$-UTR region of the SMAD7 or ACVR2A mRNA. Specific primers and 50-mer mutated oligonucleotides were designed based on bovine SMAD7 (XM_005224232.3) or ACVR2A (NM_174227) mRNA sequences in GenBank (Additional file 1: Table S1). The luciferase activity was measured $48 \mathrm{~h}$ after transfection using the pmirGLO Dual Luciferase ${ }^{\curvearrowleft}$ Reporter Assay System (Promega
Corporation, USA) according to the manufacturer's protocol. Firefly and Renilla luciferase activity was detected by measuring the absorbance on a Centro LB 960 Microplate Luminometer (Berthold Technologies GmbH, Germany).

\section{Total RNA isolation and CDNA synthesis}

To confirm the expression of target and marker genes in treated bGCs at each stage of the experiment, harvested bGCs were resuspended in lysis buffer, and the subsequent RNA isolation was performed using an miRNeasy ${ }^{\circ}$ mini kit (Qiagen $\mathrm{GmbH}$, Germany) following the manufacturer's protocol. Total RNA quantity and purity (260/ 280 ratios) was measured with a NanoDrop 8000 spectrophotometer (NanoDrop products, USA). After validating the quality and concentration of the RNA samples, the cDNA synthesis was performed using a RevertAid first stand cDNA synthesis kit (Thermo Fisher Scientific, Germany). Briefly, each RNA sample $(1 \mu \mathrm{g})$ was coincubated with $1 \mu \mathrm{l}$ of Oligo $(\mathrm{dT})_{18}$ primer and $\mathrm{dH}_{2} \mathrm{O}$ to a total of $11 \mu \mathrm{l}$ at $65{ }^{\circ} \mathrm{C}$ for $5 \mathrm{~min}$ and then chilled on ice for $5 \mathrm{~min}$. The reverse transcription was performed in a total mixture volume of $20 \mu \mathrm{l}$ consisting of $4 \mu \mathrm{l}$ of $5 \times$ Reaction Buffer, $1 \mu \mathrm{l}$ of RevertAid Reverse Transcriptase, $2 \mu \mathrm{l}$ of dNTP mix and $1 \mu \mathrm{l}$ of RiboLock RNase Inhibitor. The reactions were carried out in a thermocycler programmed at $37{ }^{\circ} \mathrm{C}$ for $60 \mathrm{~min}$ followed by $70{ }^{\circ} \mathrm{C}$ for $5 \mathrm{~min}$.

\section{Quantitative real-time polymerase chain reaction (qRT- PCR)}

Primers for specific genes were designed using the Primer-BLAST program (http://www.ncbi.nlm.nih.gov/ tools/primer-blast/). The details of the primers are described in Additional file 1: Table S2. The specificity of each primer amplicon was confirmed by sequencing the PCR products using a GenomeLab GeXP Genetic Analysis System (Beckman Coulter $\mathrm{GmbH}$, Germany). The qRT-PCR analysis of mRNA was performed in an Applied Biosystem ${ }^{\circ}$ StepOnePlus ${ }^{\text {Tw }}$ System (Thermo Fisher Scientific Inc., USA), using iTaq ${ }^{\mathrm{Tm}}$ Universal SYBR ${ }^{\circ}$ Green Supermix (Bio-Rad Laboratories $\mathrm{GmbH}$, Germany), with the program described previously [23, 29] The mRNA expression data were analysed using the comparative $\mathrm{Ct}$ $\left(2^{-\Delta \Delta C t}\right)$ method [38], and $\beta$-ACTIN was used as an internal control.

Candidate miRNAs were quantified as described previously [23, 29]. Briefly, cDNA was synthesized using $80 \mathrm{ng}$ of miRNA-enriched total RNA using a miRCURY LNA $^{\mathrm{Tm}}$ Universal cDNA synthesis kit (Exiqon, Denmark) according to the manufacturer's instructions. The synthesized cDNA was diluted $40 \times$ and used for the qRTPCR analysis of candidate miRNAs using ExiLENT SYBR Green Master mix (Exiqon, Denmark). The 


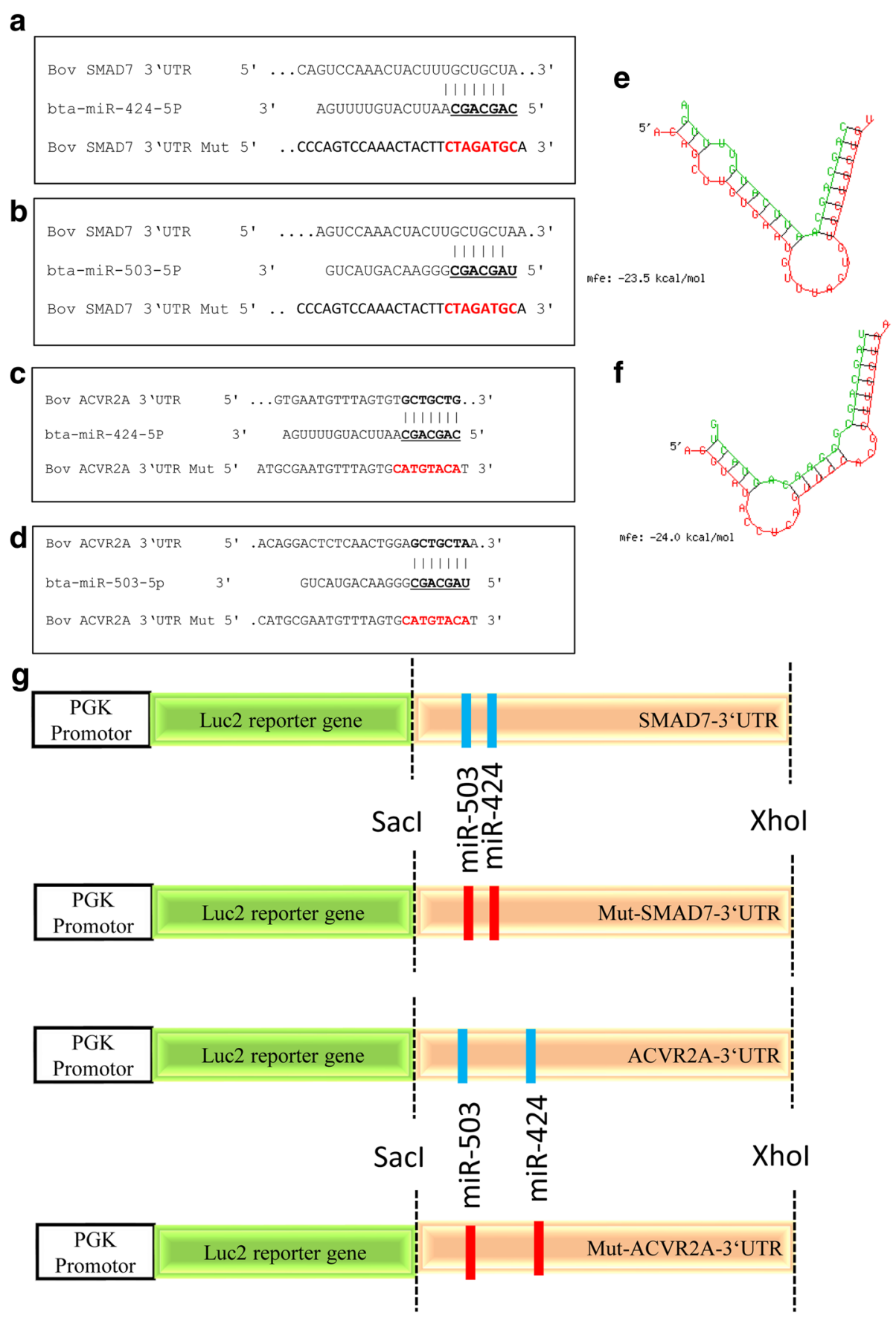

Fig. 1 The miRNA-mRNA binding sites in bovine SMAD7 3'-UTR $(\mathbf{a}, \mathbf{b})$ and ACVR2A 3'-UTR sequences (c, $\mathbf{d})$, Bold and underlined letters indicate putative binding sites and mutated regions. The minimum free energies ( $\mathrm{kcal} / \mathrm{mol})$ of miR-424 (e) and miR-503 (f). Schematic diagram of the reporter constructs containing the putative miRNA-mRNA binding sites of the bovine SMAD7 and ACVR2A 3'-UTR sequences (g)

thermal cycling program was used as described previously $[23,29]$. The specificity of the miRNA amplification was evaluated by melting curve analysis. The $5 \mathrm{~s}$ ribosomal RNA (5 s rRNA) (miRCURY LNA ${ }^{\text {тx }}$ Universal RT microRNA PCR) was used as the reference gene primer. The qRT-PCR data were analysed using the comparative $\mathrm{Ct}\left(2^{-\Delta \Delta \mathrm{Ct}}\right)$ method [38].

\section{Western blot analysis}

Total protein from cultured bGCs was isolated using $1 \times$ PLB (Promega Corporation, USA). The total protein concentration was determined using the Bradford method [39]. Western blotting was performed as described previously $[12,13]$. The antibodies used were (Santa Cruz Biotechnology Inc., Germany): anti-ACTR- 
II2A goat polyclonal antibody (product no. sc-5667), anti-SMAD7 rabbit polyclonal antibody (product no. sc11,392 ), anti-PCNA rabbit polyclonal antibody (product no. sc-7907), anti-STAR rabbit polyclonal antibody (product no. sc-25,806), anti-SMAD2/3 rabbit poly clonal antibody (product no.sct-5678), anti-psmad2/3 rabbit monoclonal antibody (sct-8828) or anti- $\beta$-ACTIN mouse monoclonal antibody (product no. sc-47,778). At the end of the incubation period, the membrane was washed six times with $1 \times$ TBST and incubated with the corresponding donkey anti-goat, goat anti-rabbit, or goat anti-mouse secondary antibody conjugated to horseradish peroxidase (Santa Cruz Biotechnology). The detection of the protein signal was then performed using Clarity Western ECL Substrate (Bio-Rad Laboratories). The relative band intensity was determined by ImageJ program (https://imagej.nih.gov/ij/).

\section{Cell proliferation assay}

A total of $2 \times 10^{4}$ bGCs per well were seeded into a 96well plate as described previously [12, 13] Individual miR-424/503 mimics, inhibitors or corresponding controls were transfected into sub-confluent cultured bGCs (70-80\% confluent). After $48 \mathrm{~h}$ of incubation, $10 \mu \mathrm{l}$ of CCK-8 kit solution (Dojindo EU GmbH, Germany) was added to each well, and the plate was incubated for another $2 \mathrm{~h}$. The optical density (OD) at a wavelength of $450 \mathrm{~nm}$ was measured using a Synergy ${ }^{\mathrm{mm}}$ H1 Multi-Mode Reader (BioTek Instruments Inc., Germany).

\section{Cell cycle assay}

Cultured granulosa cells were transfected with $75 \mathrm{nM}$ miR-424/503 cluster miRNA mimics, inhibitors, or the corresponding negative control (NC) and SMAD7 siRNA, ACVR2A siRNA or NC siRNA. The cells were trypsinized $48 \mathrm{~h}$ later and collected in a $15-\mathrm{mL}$ Falcon tube (Thermo Fisher Scientific, Germany), followed by centrifugation at $750 \times g$ for $5 \mathrm{~min}$ and washing twice with 1 x CMF-PBS. A minimum of $\sim 1 \times 10^{6}$ cells were fixed in ice-cold $70 \%$ ethanol at $4{ }^{\circ} \mathrm{C}$ overnight. The cells were then centrifuged briefly, and the cell pellet was washed twice with $500 \mu \mathrm{l}$ of $1 \times$ CMF-PBS. The cells were then labelled with $50 \mu \mathrm{g} / \mathrm{mL}$ propidium iodide (PI) and treated with $50 \mu \mathrm{g} / \mathrm{mL}$ RNase. The cells were then incubated at $37{ }^{\circ} \mathrm{C}$ for $30 \mathrm{~min}$ and processed in a $\mathrm{BD}$ LSRFortessa $^{\text {aw }}$ flow cytometer (BD Biosciences). The cell cycle distribution was analysed using ModFit LT software (http://www.vsh.com/products/mflt/index.asp).

Targeted suppression of the SMAD7 and ACVR2A gene using small interfering RNA (siRNA)

Bovine specific LNA ${ }^{\mathrm{TM}}$ longRNA GapmeRs (Exiqon, USA) were used to inhibit the expression of SMAD7 $\left(5^{\prime}-\mathrm{TT}\right.$ CGCAGAGTCGGCTA-3' and 5'-CGATTTTGCTCCGT
A-3') ACVR2A (5'-GTTACTGGATTCGACG-3' and 5'GTTGGTCAGTAATCTA-3'). The transfection of $75 \mathrm{nM}$ SMAD7 siRNA, ACVR2A siRNA or control siRNA was performed as described above. The gene expression analysis and cell proliferation assays were performed as described above.

\section{Data analysis}

All the quantitative data are presented as the mean \pm standard error (SEM) and at least three biological replicates were used for each analysis. The statistical analysis was performed using GraphPad Prism ${ }^{\circ}$ 5, version 5.02. The statistical significance between the mean values of two treatment groups was determined using a two-tailed Student's t-test. However, data from more than two treatment groups were analysed using a one-way ANOVA followed by Dunnett's post hoc test. The $p$ values indicate the statistical significance as described in each figure legend.

\section{Results \\ SMAD7 and ACVR2A are the direct targets of the miRNA- 424/503 cluster members}

We demonstrated in our previous study that miR-424/ 503 cluster miRNAs were upregulated in the granulosa cells of preovulatory dominant follicles at day 19 of the oestrous cycle. MicroRNA-424/503 cluster members are transcribed from an intergenic region of chromosome $\mathrm{X}$, which is polycistronic in nature and evolutionary conserved in mammals. The precursors of bta-miR-424-5p (miR-424) and bta-miR-503-5p (miR-503) are 96 bp and 83 bp, respectively. The mature sequences of bta-424-5p and miR-503-5p are CAGCAGCAAUUCAUGUUUUGA and UAGCAGCGGGAACAGUACUG, respectively, which are conserved in other mammalian species. Since miRNAs regulate biological functions by targeting the 3 '-UTR of genes post-transcriptionally in a sequencespecific manner, we performed a computational prediction using TargetScan (http://www.targetscan.org) to generate an algorithm to identify putative targets, which revealed that miR-424 and miR-503 target SMAD7 and $A C V R 2 A$. On the other side, miRNA prediction for SMAD7 target gene using TargetScan revealed that miR424-5p was top predict with 8 mer site type (an exact match to positions $2-8$ of the mature miRNA (the seed + position 8) followed by an 'A'); while, miR-503-5p showed 7 mer-A1 site type (an exact match to positions 2-7 of the mature miRNA (the seed) followed by an 'A'). The validation of the putative target genes, SMAD7 and ACVR2A, of the miR-424/503 cluster was performed by measuring the luciferase activity of an expression vector carrying the $3{ }^{\prime}$-UTR of the SMAD7 and ACVR2A gene, which contains the miRNA binding sites. The luciferase activity in bovine granulosa cells co-transfected with 
miR-424 and miR-503 mimics and a plasmid vector harbouring the wild-type SMAD7 and ACVR2A 3'-UTR was significantly reduced compared to bGCs transfected with a control for the individual miRNA mimics and the plasmid vector with the wild-type SMAD7 and ACVR2A $3{ }^{\prime}$-UTR $(P<0.05$; Fig. 2). However, there was no significant reduction in luciferase activity in bGCs cotransfected with individual miRNA mimics or a control and a plasmid vector harbouring a mutated SMAD7 and ACVR2A 3'-UTR sequence.

\section{Modulation of the miRNA-424/503 cluster members resulted in differential expression of SMAD7 and ACVR2A mRNA levels in cultured bovine granulosa cells}

To obtain further insights into the role of the miR-424/ 503 cluster in granulosa cell function by regulating the expression of $S M A D 7$ and $A C V R 2 A$ gene, we transfected cultured bGCs with either the miR-424/503 mimics, inhibitors or the corresponding controls at a concentration of $75 \mathrm{nM}$. The expression level of the SMAD7 and ACVR2A mRNA was determined by qRT-PCR analysis $48 \mathrm{~h}$ after transfection. Transfection of the miR-424/503 cluster members mimic resulted in a significant reduction in the relative abundance of SMAD7 $(P<0.01)$ and ACVR2A $(P<0.05)$ mRNA compared to the controls (Fig. 3a). Transfection of miR-424/503 inhibitors did not affect, the expression of $S M A D 7$ mRNA while the expression of $A C V R 2 A$ mRNA was increased. The western blot analysis showed that bGCs transfected with miR$424 / 503$ cluster mimics had no significant reduction in
SMAD7 and ACVR2A protein levels compared to those transfected with negative controls The miR-424/503 cluster inhibitors had no significant change in SMAD7 and ACVR2A protein expression compared to those transfected with controls (Fig. 3b).

\section{Overexpression of the miRNA-424/503 cluster members enhanced the proliferation and reduced the differentiation of bovine granulosa cells}

MiR-424 mimic transfection in cultured bGCs significantly increased the proliferation activity in cells transfected with a miRNA mimic negative control (Fig. 4a). However, miR-503 had no significant effect on cell proliferation. Conversely, compared to the miRNA inhibitor control, bGCs transfected with miR-424 and miR-503 inhibitors showed no significant differences in proliferation activity. Moreover, the cell proliferation phenotype was accompanied by the higher expression level of the proliferation marker gene PCNA in the bGCs transfected with the miR-424 mimic compared to those transfected with the mimic control $(P<0.01)$. However, transfection of inhibitors resulted in a slight reduction in the expression of PCNA (Fig. 4b). The PCNA protein expression showed an increasing tendency in bovine granulosa cells transfected with the miR-424/503 cluster mimic (Fig. 4c).

As a marker of differentiation, the expression of the STAR gene was investigated after modulation of the miRNA cluster. Transfection of miR-424/503 cluster mimic resulted in a significant reduction in STAR gene

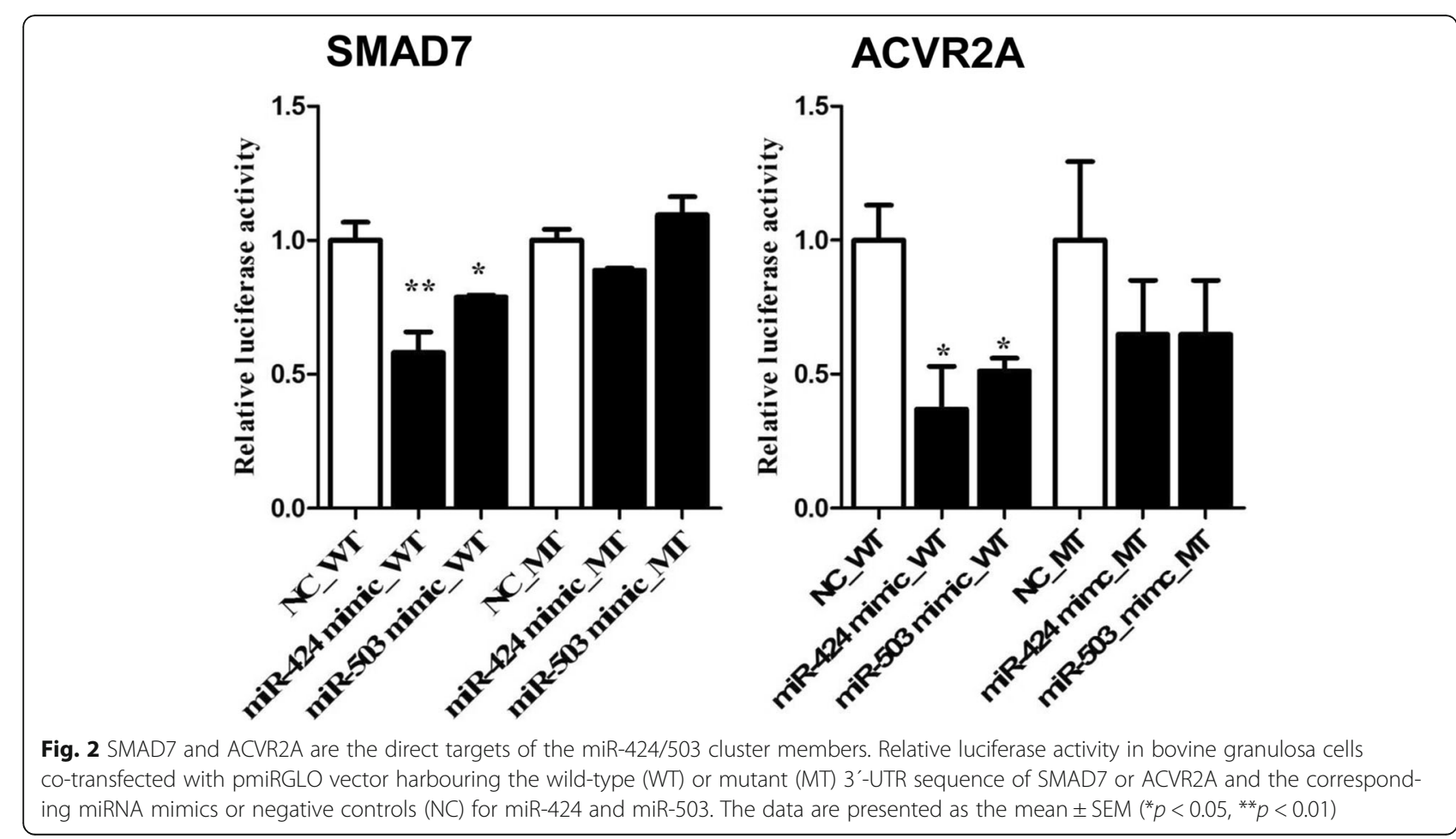



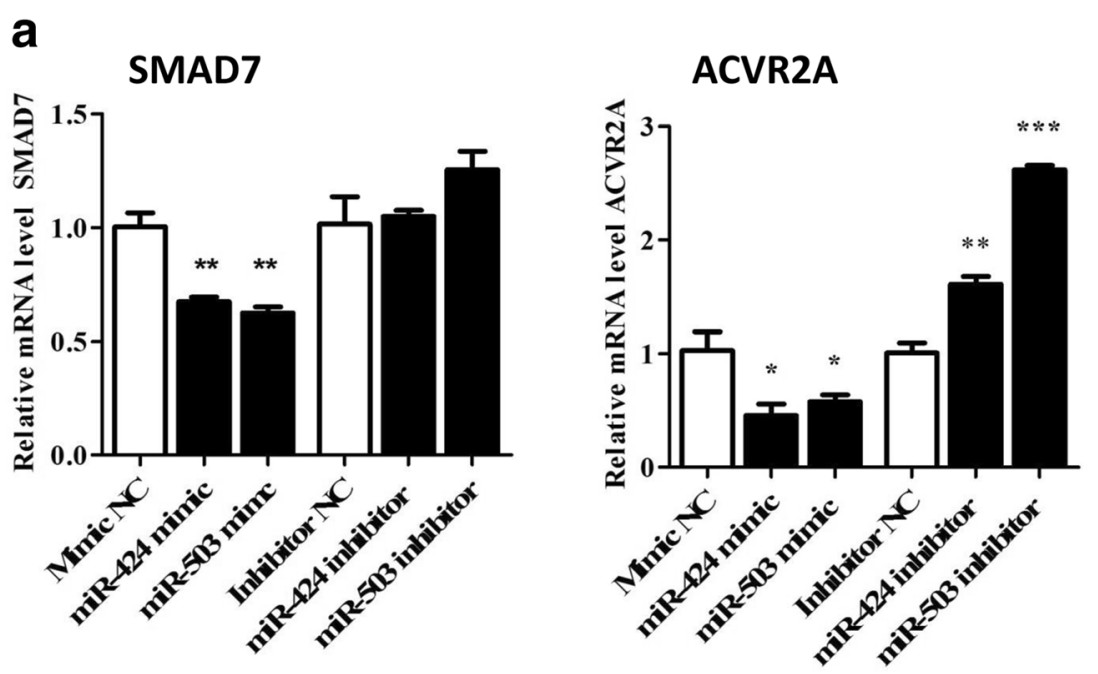

b
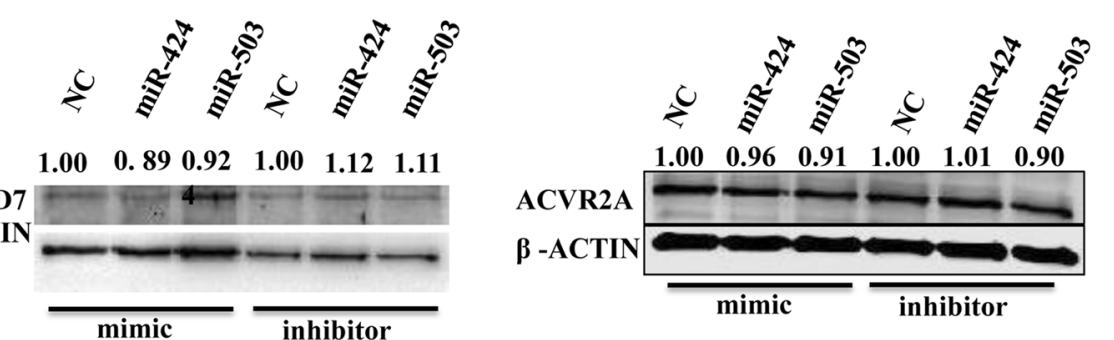

Fig. 3 Modulation of the miR-424/503 cluster members altered the expression of SMAD7 and ACVR2A in bovine granulosa cells. Overexpression of miR-424 and miR-503 decreased the SMAD7 and ACVR2A mRNA (a) and protein (b) expression. The bar graphs indicate the mean \pm SEM $\left({ }^{*} p<0.05,{ }^{* *} p<0.01,{ }^{* *} p<0.001\right)$. Numbers above western blots represent relative protein density

expression compared to the negative control (Fig. 4b, c). These results suggest that $\mathrm{miR}-424$ promotes bovine granulosa cell proliferation and decreases the terminal differentiation of the bGCs, which leads to follicular survival and development.

Furthermore, we investigated the role of miR-424/503 on downstream members of the activin signalling pathway; the western blot results showed that the expression of the SMAD2/3 proteins tended to increase after the overexpression of the miR-424 mimic compared to the negative control (4D). Moreover, the overexpression of the miR-424 mimic did not change the phosphorylated SMAD2/3 protein level (4D). Overexpression of miR503 mimic could not increase the expression of SMAD2/3 or phosphorylated SMAD2/3 protein level compared to mimic negative control (4D).

\section{Overexpression of the miRNA-424/503 cluster members} enhanced the cell cycle transition from G1- to S-phase in bovine granulosa cells

To further confirm the proliferation results and to understand the role of the miR-424/503 cluster in modulating the cell cycle of bGCs, we performed flow cytometric analysis after transfection of the miR-424/503 cluster members. The overexpression of the miR-424 mimic resulted in a significant reduction $(P<0.001)$ in the number of cells in G0/G1-phase, while a significant increase $(P<0$. $01)$ in the percentage of cells in S-phase was observed compared to cells transfected with the mimic negative control (Fig. 5g). This result indicated that the overexpression of miR-424 could increase bovine granulosa cell proliferation by promoting G1- to S-phase cell cycle transition. In contrast, the miR-424/503 cluster inhibitor did not cause any measurable changes in the cell cycle profile of bovine granulosa cells (Fig. 5h).

Effect of sequence specific knockdown of the SMAD7 and ACVR2A gene in bovine granulosa cells

In order to investigate the involvement of SMAD7 in bGCs proliferation and differentiation, and to further validate the regulatory role of the miR-424/503 cluster in SMAD7 expression, we performed an independent experiment by knocking down the expression of SMAD7 using small interfering RNA (siRNA). Bovine GCs transfected with the SMAD7 siRNA showed a significant reduction in the expression of both SMAD7 mRNA $(P<0$. $05)$ and protein compared to cells transfected with the siRNA negative control (Fig. 6a, e). The transfection of 

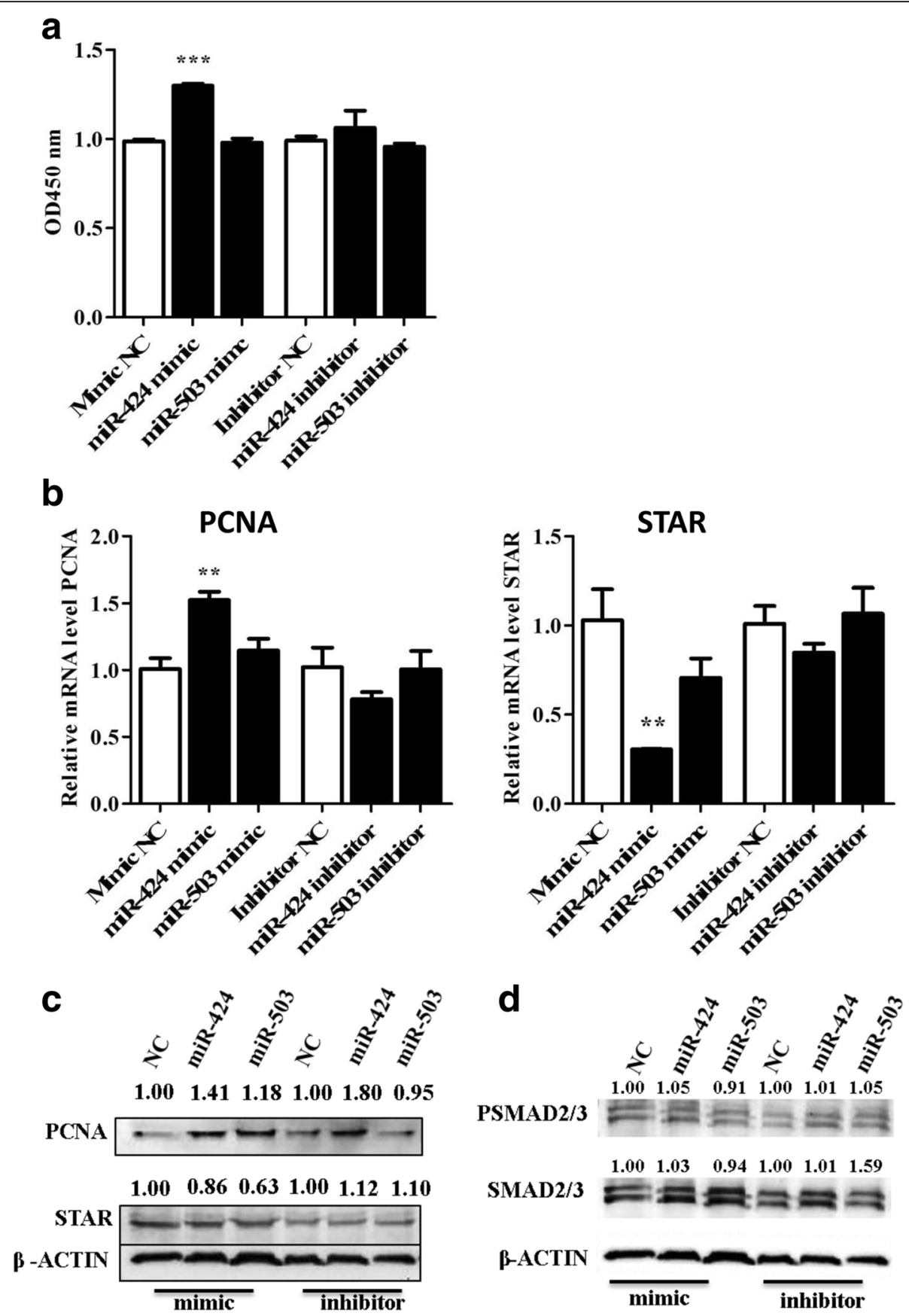

Fig. 4 Overexpression of the miR-424/503 cluster members increased bovine granulosa cell proliferation. Cell proliferation assay of granulosa cells transfected with miR-424/503 cluster mimics and inhibitors and the corresponding negative control (NC) (a). The mRNA (b) and protein (c) expression level of PCNA and STAR in granulosa cells transfected with miR-424/503 cluster mimics, inhibitors or corresponding NC. The protein expression level of SMAD2/3 and phosphorylated SMAD2/3 in granulosa cells transfected with miR-424/503 cluster mimics and inhibitors and the corresponding NC (d). The bar graphs indicate the mean \pm SEM $\left({ }^{* *} p<0.01,{ }^{* *} p<0.001\right)$. Numbers above western blots represent relative protein density

bGCs with the SMAD7 siRNA significantly enhanced proliferation of bGCs compared to siRNA negative control (Fig. 6b), which was accompanied by noteworthy change in the expression of the marker of proliferation PCNA (Fig. 6c). However, flow cytometric analysis showed reduction $(P<0.001)$ in the number of cells in G0/G1-phase (Fig. 6j), while a significant increase $(P<0$. 01 ) in the percentage of cells in S-phase (Fig. 6j) was observed compared to cells transfected following knocking down of SMAD7 with siRNA compared to negative 


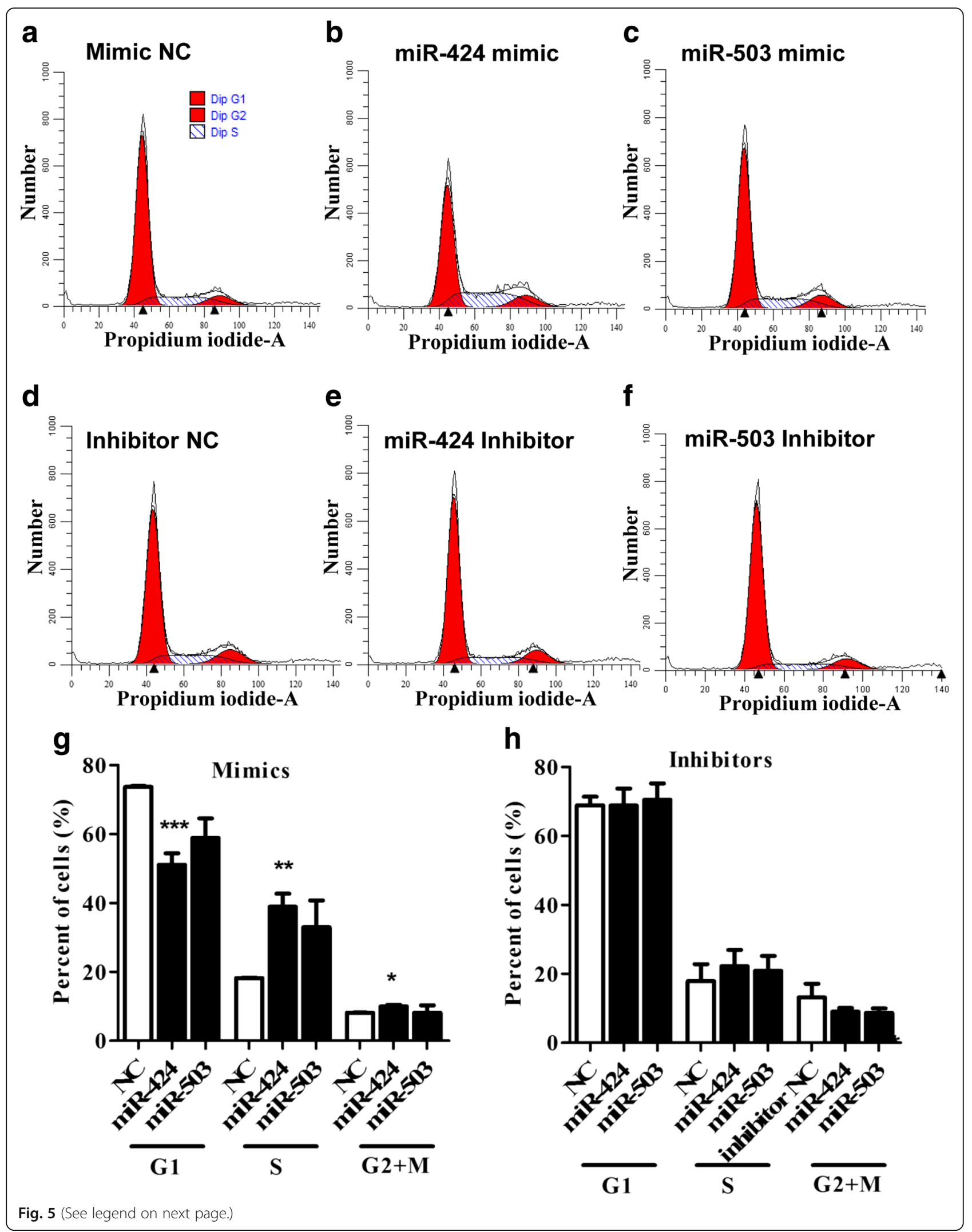


(See figure on previous page.)

Fig. 5 Overexpression of the miR-424/503 cluster members enhanced cell cycle progression of bovine granulosa cells. Flow cytometric analysis showing the cell cycle distribution (G1/G0, S and G2/M phases) of propidium iodide (PI)-labeled bovine granulosa cells transfected with the mimic negative control (NC) (a), miR-424 mimic (b), miR-503 mimic (c), inhibitor NC (d), miR-424 inhibitor (e), or miR-503 inhibitor (f). Bar graphs showing the percentages of cells in G1/G0, S and G2/M phases of the cell cycle after transfection with miR-424/503 cluster mimics (g), and inhibitors (h). The bar graphs indicate the mean \pm SEM $\left({ }^{*} p<0.05,{ }^{* *} p<0.01,{ }^{* *} p<0.001\right)$

control. Further, the suppression of the SMAD7 gene using siRNA had no effect on the expression of the STAR gene and STAR protein (Fig. 6d, g). Western blot analysis showed that the expression of SMAD2/3 and phosphorylated SMAD2/3 was slightly increased in siRNA-transfected cells compared to cells transfected with the negative control (Fig. 6f).

Similarly, to investigate the possible involvement of $A C V R 2 A$ in bGCs proliferation and differentiation and to further validate the regulatory role of the miR-424/ 503 cluster in $A C V R 2 A$ expression, we suppressed ACVR2A using small interfering RNA (siRNA). Bovine GCs transfected with the ACVR2A siRNA showed a significant reduction in the expression of both $A C V R 2 A$ mRNA $(P<0.01)$ and protein compared to cells transfected with the siRNA negative control (Fig. 7a, e). The transfection of bGCs with the ACVR2A siRNA did not result in any measurable effect on the proliferation of bGCs compared to control siRNA-transfected bGCs (Fig. 7b). Similarly, there was no noteworthy change in the expression of the marker of proliferation PCNA following the suppression of the ACVR2A gene (Fig. $7 \mathrm{c})$. However, western blot analysis showed reduced expression of the PCNA protein (Fig. 7f). Flow cytometric analysis showed no change in G1/S cell cycle transition (Fig. 7j). Further, the suppression of the ACVR2A gene using siRNA had no effect on the expression of the STAR gene (Fig. 7d). Western blot analysis showed that the expression of SMAD2/3 and phosphorylated SMAD2/3 was slightly decreased in siRNA-transfected cells compared to cells transfected with the negative control (7G).

\section{Activin treatment decreased SMAD7 and miRNA-424/503 cluster members expression in bovine granulosa cells through activin signalling pathway}

Activin has been implicated in various intra-ovarian roles, including granulosa cell proliferation, follicular luteinization retardation and the recruitment of R-SMADs to activate the activin signalling pathway. Here, we investigated the effect of Activin A treatment on the proliferation of granulosa cells and on miR-424/503 cluster expression. We treated bGCs with different doses of Activin A (25 ng/mL, $50 \mathrm{ng} / \mathrm{mL}$ and $100 \mathrm{ng} / \mathrm{mL})$. We found that Activin A treatment increased proliferation of bovine granulosa cells in dose-dependent manner (Fig. 8a). Activin A treatment significantly decreased
$(P<0.001)$ the STAR expression compared to control cells (Fig. 8c), which indicates a decrease in bGCs differentiation. Further, we also noticed that Activin A treatment in dose dependent manner significantly decreased the expression of SMAD7 $(P<0.01$; Fig. 8e); however, there was no change in the expression of ACVR2A (Fig. 8f). Interestingly, we observed a dosedependent reduction in miR-424/503 expression upon treatment with Activin A. miRNA-424 was significantly decreased $(P<0.05$; Fig. $8 \mathrm{~g})$ at the $100 \mathrm{ng} / \mathrm{mL}$ dose of Activin A. This result indicates that there might be negative feedback loop between Activin A and the miR-424/503 cluster. These results indicated that there could be possibility that miR-424/503 might be involved in fine tuning of the activin signalling pathway.

\section{Discussion}

Folliculogenesis is a highly dynamic and wellcoordinated process in which granulosa cells support follicular growth and development by producing hormones, autocrine and growth factors, and cytokines [5, 6] under the control of several molecular mechanisms and pathways. Increasing evidence supports the idea that miRNAs are one of the molecular mechanisms that epigenetically regulate the follicular development process $[12,13,23,40]$. Several studies have shown that miRNAs regulate cumulus cell development and granulosa cell function by targeting TGF- $\beta$ superfamily members [4144]. In our previous study, we demonstrated that the miR-424/503 cluster was upregulated in bovine granulosa cells from preovulatory dominant follicles compared to those derived from subordinate follicle [23], which indicated the potential involvement of the miR-424/503 cluster in granulosa cell function to support ovulation. In the present study, we have demonstrated the role of miR-424/503 in bovine granulosa cell function through targeting $S M A D 7$ and further through coordinating activin signalling pathway. SMAD7 and $A C V R 2 A$ genes, which are important in reproduction [36, 37, 45], were identified as a putative targets of the miR-424/503 cluster, and subsequently validated by luciferase assay (Fig. 2). Further, overexpression of the miR-424/503 cluster reduced the expression of $S M A D 7$ and $A C V R 2 A$ mRNA levels. These results suggested that the miR-424/503 cluster members target SMAD7 and ACVR2A genes. However, since one miRNA could target some other potential target genes, we also believed that in addition to 


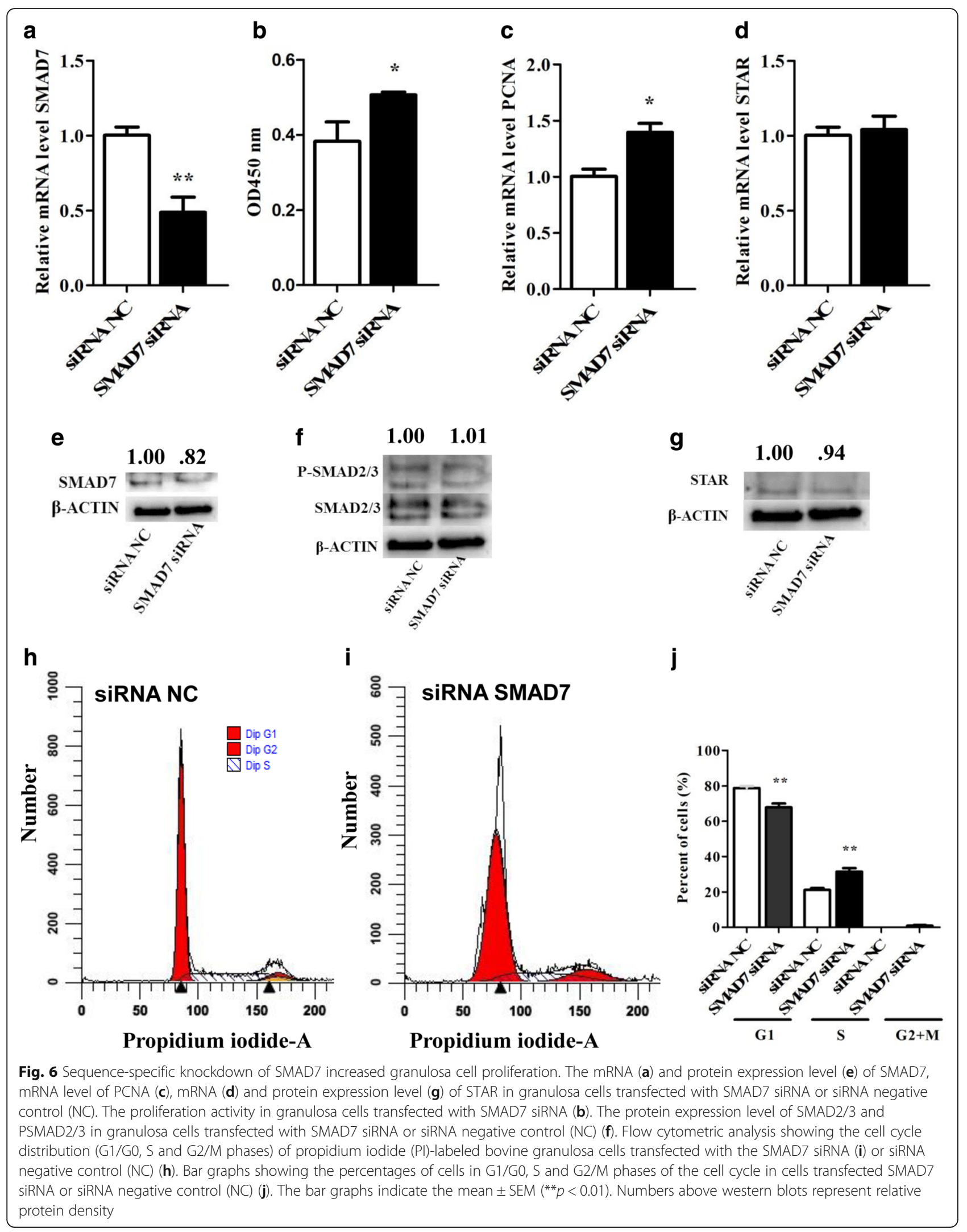




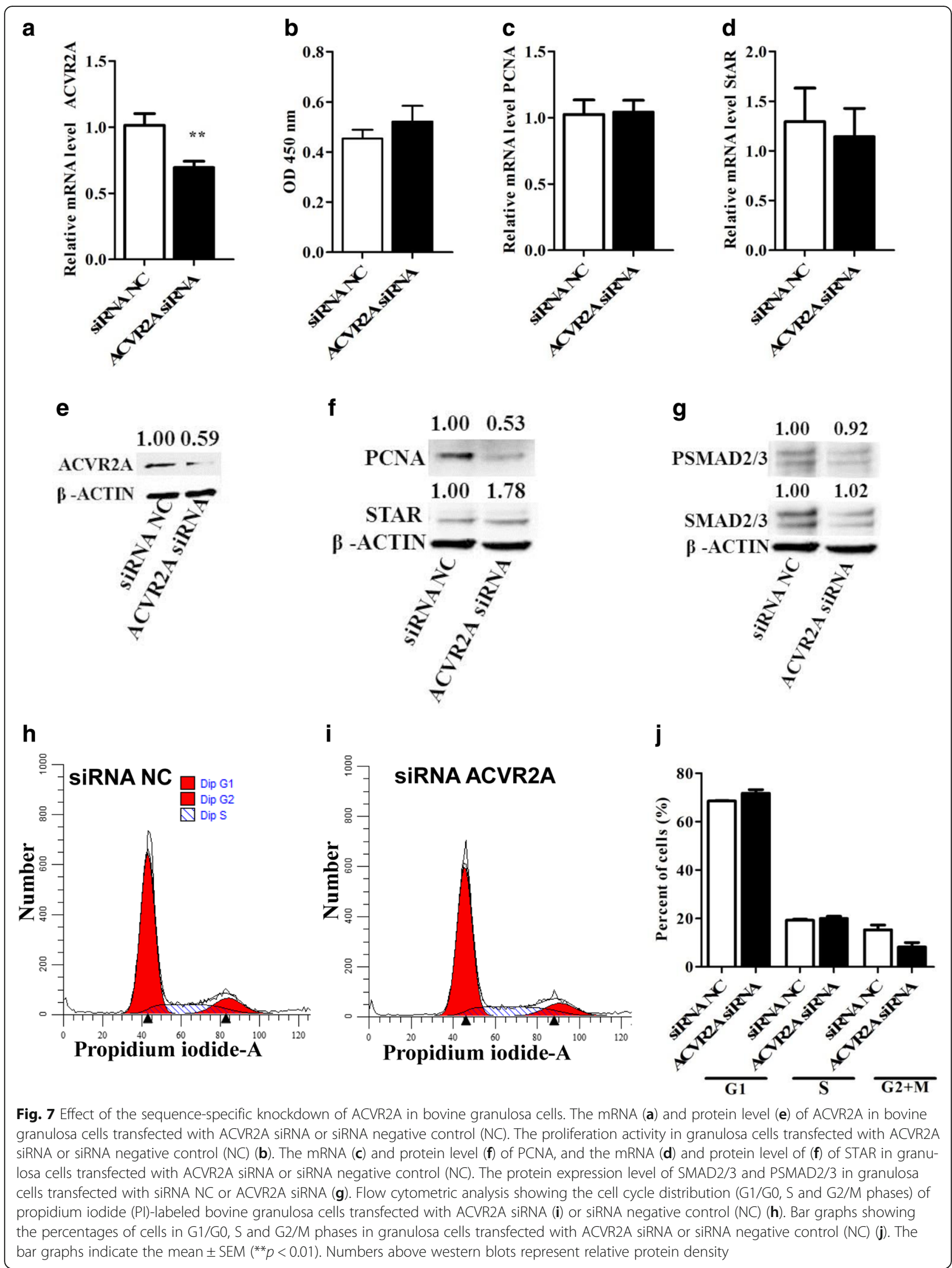




\section{a}

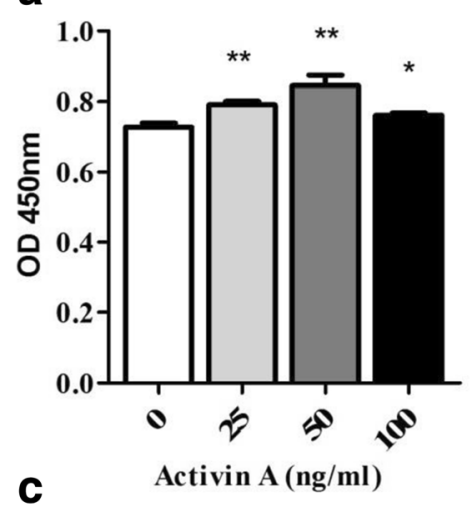

C

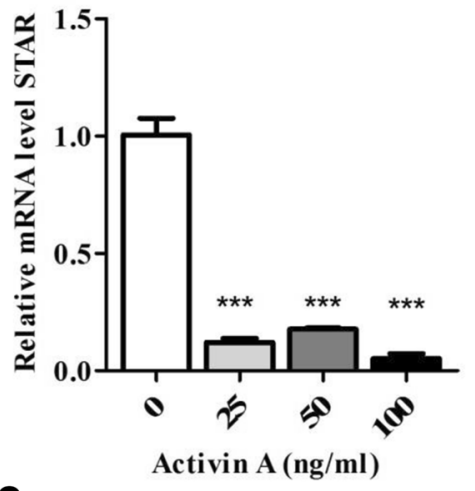

e

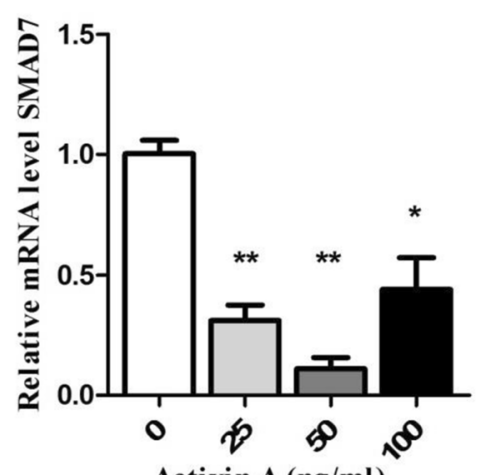

g

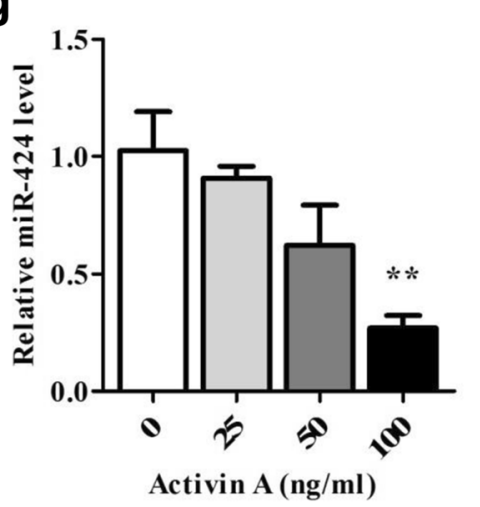

b

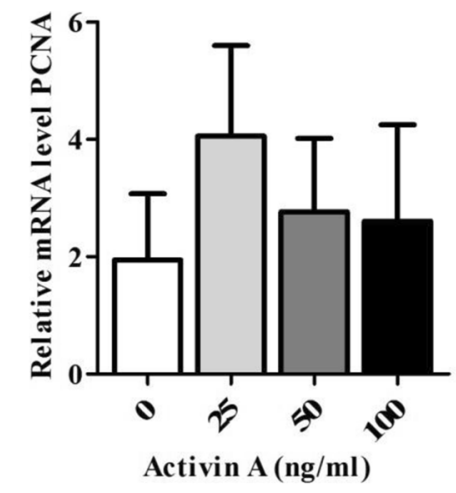

d

$$
\begin{array}{llll}
1.0 & 0.97 & 0.47 & 0.78
\end{array}
$$

STAR

$\beta$-ACTIN

-

$\forall$ s

Activin A ng/ml
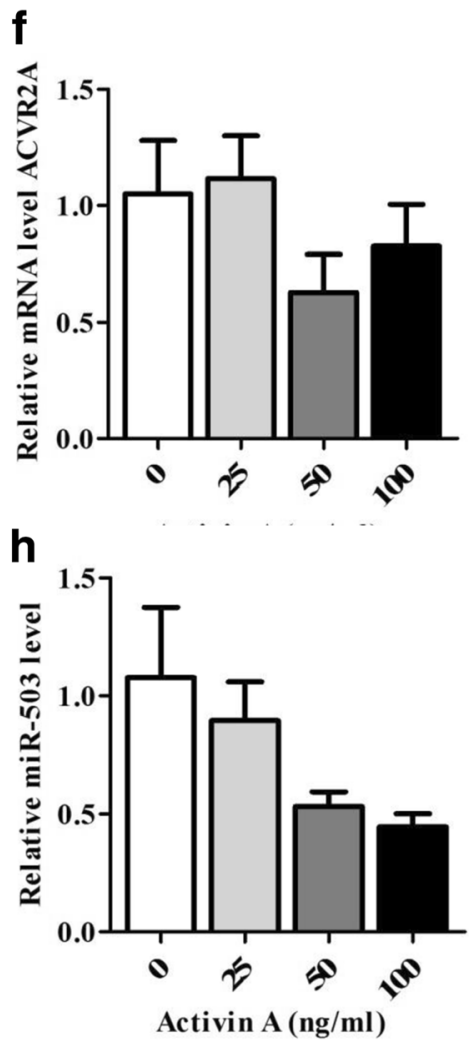

Fig. 8 (See legend on next page.) 
(See figure on previous page.)

Fig. 8 Dose-dependent activin A treatment increased bovine granulosa cell proliferation, reduced the SMAD7 and miR-424/503 expression levels. Cell proliferation assay (a) after dose-dependent Activin A treatment (Activin A: $25 \mathrm{ng} / \mathrm{mL}, 50 \mathrm{ng} / \mathrm{mL}$ and $100 \mathrm{ng} / \mathrm{mL}$ ). The relative expression levels of PCNA (b), STAR (c), SMAD7 (e), ACVR2A (f), miR-424 (g) and miR-503 (h) in granulosa cells treated Activin A. The protein expression of STAR in granulosa cells treated with treated Activin A (d). The bar graphs indicate the mean \pm SEM $\left({ }^{* *} p<0.01,{ }^{* * *} p<0.001\right)$. Numbers above western blots represent relative protein density

SMAD7 and ACVR2A genes several other target genes of these miRNAs may also be involved in regulating bovine granulosa cell functions.

The present study demonstrates that granulosa cell proliferation was significantly increased upon the overexpression of miR-424, which was accompanied by upregulation of the PCNA gene. The evidence of the effect of modulating the expression of the miR-424/503 cluster members on granulosa cell proliferation was accompanied by a shift in the proportion of cells from the G0/G1phase to the S-phase of the cell cycle. This finding is consistent with those of several reports demonstrating that miRNAs are essentially involved in the regulation of granulosa cell proliferation [13, 24, 46-48], which is necessary for follicular growth and creation of the unique micro-environment for oocyte maturation [49]. Furthermore, the proliferating granulosa cells in growing follicles depend on growth factors for their survival, which promote the G1-. to S-phase transition of the cell cycle and prevent apoptosis in granulosa cells with a lowprogesterone environment that helps to persist and sustain the dominant follicle [50-52]. Interestingly, the present study showed a significant effect of miR-424 on granulosa cell proliferation compared to miR-503. This differential role of miR-424 could be associated with the fact that relative abundance of miR-424 was found to be high compared to miR-503 in granulosa cells of preovulatory dominant follicles in our previous study [23].

Several studies have shown that TGF- $\beta$ superfamily members involved in granulosa cell proliferation are post-transcriptionally regulated by several classes of miRNAs [41, 47, 53]. Further, studies suggested SMAD7 antagonizes TGF- $\beta$ superfamily, and acts as potential regulator of ovarian function $[36,45]$. In the present study, we demonstrated that $S M A D 7$, which belongs to the TGF- $\beta$ signalling pathway, is a direct target of miR424/503 cluster members. Further, we have also shown knocking down of inhibitor SMAD (SMAD7) enhanced granulosa cell proliferation in in vitro, which was accompanied by increased expression of proliferation marker gene PCNA and further substantiated by granulosa cell cycle transition from G1- to S-phase. However, the function of SMAD7 in the ovary remains poorly understood. In one of the study, [45]) showed that SMAD7 expresses in granulosa cells and subject to regulation by intraovarian growth factors from the TGF- $\beta$ superfamily. In the same study small interfering RNA demonstrated that SMAD7 acted a negative regulator of TGF $\beta 1$ and revealed a link between SMAD7 and GDF9-mediated oocyte paracrine signalling, an essential component of oocyte-granulosa cell communication. This suggested that SMAD7 function during follicular development via preferentially antagonizing and/or fine-tuning TGF- $\beta$ superfamily signalling involved in the regulation of granulosa cell function [45]. Further, in another study [42], it was reported that MiR-92a inhibits porcine ovarian granulosa cell apoptosis by targeting Smad7 gene. In our study, we also noticed the similar finding that miR-424 promotes bovine granulosa cell proliferation by targeting the SMAD7 gene.

This suggests that miR-424/503 cluster member might be involved to control the activin signalling pathway through regulation of the inhibitory effect of SMAD7. Similarly, the cell cycle analysis results showed that overexpression of miR-424/503 resulted significant number of cells to be at S-phase compared to the untreated controls, which further validated proliferation assay of bovine granulosa cells. However, inhibition of both miRNAs did not result any change in cell cycle status of the granulosa cells compared to the untreated controls.

Addition of Activin A in in vitro cultured granulosa cells enhanced cell proliferation in dose-dependent manner (Fig. 8a), as it has been reported previously [41, 54]. Similarly, treatment of granulosa cells with varying doses $(25,50,100 \mathrm{ng} / \mathrm{mL})$ of Activin A sharply decreased the mRNA and protein expression of STAR (Fig. 8d). Similar studies also have shown that Activin A downregulates STAR expression and progesterone production in granulosa cells through SMAD2/3 phosphorylation [55], which ultimately helps to prevent or delay the premature luteinization of bovine granulosa cells [56]. We showed that similar to Activin A, the overexpression of the miR424/503 cluster members clearly reduced STAR expression, which suggests the potential role of the miR-424/ 503 cluster members in the establishment and maintenance of the dominant follicle and further indicate involvement of miR-424/503 cluster members in activin signalling pathway.

The TGF- $\beta$ - SMAD pathways are known to be an integral part of a range of biological processes and are errantly activated or inactivated under various biological conditions $[57,58]$. SMAD proteins are potentially involved in controlling the transcription of a variety of 
miRNA genes, and this transcriptional activation of miRNAs has distinct physiological significance [58]. For instance, TGF- $\beta$ induces both miR-216a and miR-217 in glomerular mesangial cells via SMAD binding elements (SBEs) in the miR-216 promoter [59]. In contrast, TGF- $\beta$-induced SMAD3/4 complex binding to the miR-24 promoter inhibits the expression of miR24 in myoblasts [60]. Interestingly, dose-dependent activin A treatment reduced the expression of miR$424 / 503$, whereas at a higher dose $(100 \mathrm{ng} / \mathrm{ml})$ significantly reduced the expression of miR-424 (Fig. 8g). This indicates possibility of negative feedback loop between the miR-424/503 cluster members and activin-SMAD2/3 signalling. Here, we proposed a hypothetical model illustrating the involvement of the miR-424/503 cluster members in regulating the activin signalling pathway (Fig. 9). In line to this, a report by Wang et al [53], which showed the presence of a potential feedback loop between miRNAs and the target gene.

Follicular growth and development is a dynamic and complex but nonetheless tightly harmonized process where activin plays an important role by enhancing the

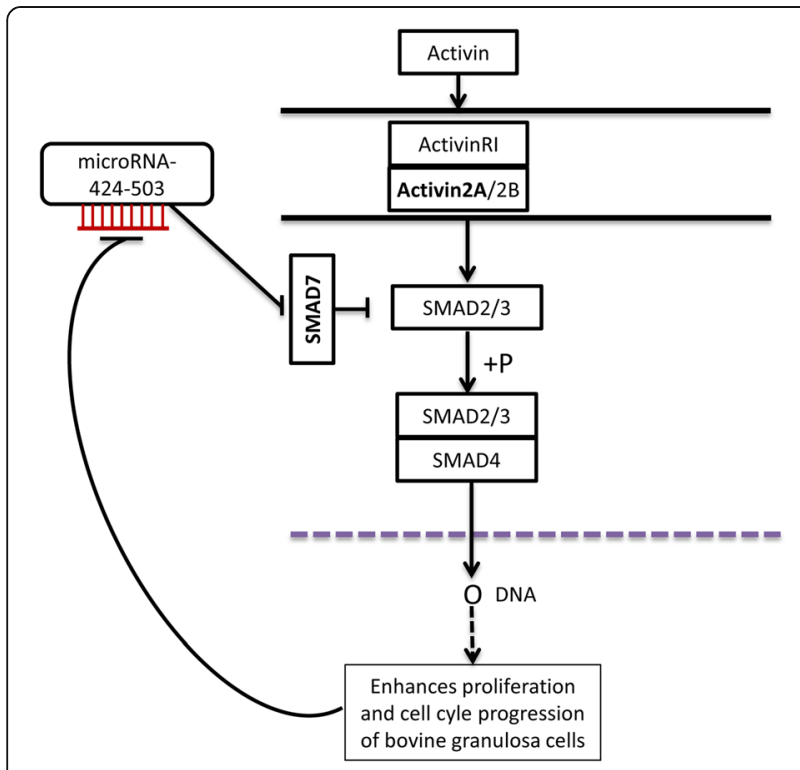

Fig. 9 Proposed hypothetical model depicting the involvement of miR-424/503 cluster in the Activin signalling pathway by targeting SMAD7. Increased expression of miR-424/503 cluster suppresses the expression of SMAD7 which eventually increases the phosphorylation of SMAD2/3 and subsequently promotes the granulosa cell proliferation and cell cycle progression. Thus, when granulosa cells are treated with Activin A, the SMAD7 expression is suppressed, but the ACVR2A expression was maintained and leading to enhanced cell proliferation. At the time when the cells reach peak proliferation activity, the miR-424/503 expression was suppressed indicating the presence of negative feed back loop between the expression of miR-424/503 and cell proliferation activity in Activin A treated cells proliferation and reducing the differentiation of granulosa cells [61-63]. Several studies have shown that the dysfunction of granulosa cells may contribute to the abnormal folliculogenesis observed in ovarian pathophysiology [64-66], although the underlying mechanism remains to be determined. Furthermore, it is also important that granulosa cells should proliferate in controlled manner to avoid granulosa cell tumours, which account for $2-3 \%$ of ovarian malignancies [67]. Here, we reveal for the first time that the miR-424/ 503 cluster members are involved not only in the proliferation of granulosa cells but also in the balancing of the activin signalling pathway through regulating the expression of SMAD7 and ACVR2A in bovine granulosa cells. This coordination of the activin signalling pathway through miRNAs might lead to healthy granulosa cells by avoiding any deviation from normalcy, like granulosa cell tumours. Previous studies have shown that miRNA-424-5p suppresses the expression of SOCS6 in pancreatic cancer [68] and inhibits the Akt3/E2F3 axis and tumour growth in hepatocellular carcinoma [30]. Here, we suggest that perturbations in the expression of the miRNA-424/ 503 cluster members might result in ovarian disorders such as PCOS (polycystic ovarian syndrome) and granulosa cell tumours. Therefore, these results suggest that an optimal miRNA milieu is required for normal cellular and tissue function. The present study and other related miRNA studies provide insights into the molecular mechanisms underlying the regulation of granulosa cell functions and can facilitate a better understanding of follicular development and the pathophysiology of some reproductive disorders for the improvement of fertility treatments.

\section{Conclusion}

In the present study, the luciferase assay showed SMAD7 and ACVR2A genes to be the target genes of the miRNA-424/503 cluster members. Overexpression of miR-424/503 cluster members promoted granulosa cell proliferation and cell cycle progression accompanied by downregulation of the SMAD7 and ACVR2A mRNA expression level. On the other hand, knockdown of the SMAD7 not the ACVR2A mRNA expression level in granulosa cells resulted in similar phenotype characteristics that were obtained by overexpression of miR-424/ 503 cluster. Thus, the interplay between the miR-424/ 503 cluster members and SMAD7 gene might be involved in the complex and coordinated process of bovine granulosa development. Nevertheless, apart from SMAD7 gene, other target genes of the miRNA-424/503 cluster members might be involved in the regulation of bovine granulosa cell proliferation and cell cycle progression. Thus, additional study is required to further 
screen and identify downstream genes of miR-424/503 cluster members that are associated with granulosa cell function.

\section{Additional file}

Additional file 1: Table S1. Sequence specific primers used for pmirGLO and 3'-UTR amplification of the SMAD7 and ACVR2A gene harboring binding site for miR-424-5p and miR-503-5p. Table S2. Sequence specific primers used for analysis of the relative expression of genes. (PDF 83 kb)

\section{Abbreviations}

ACVR2A: Activin receptor type 2 A; bGCs: Bovine granulosa cells; cDNA: Complementary DNA; DMEM: Dulbecco modified eagle medium; FBS: Fetal bovine serum; miRNA-424/503 cluster: microRNA-424/503 cluster; NC: Negative controls; PCNA: Proliferating cell nuclear antigen; qRTPCR: Quantitative real time polymerase chain reaction; RBC: Red blood cell; SiRNA: Small interfering RNA; SMAD2: SMAD family member 2; SMAD3: SMAD3 family member 3; SMAD7: SMAD7 family member 7; STAR: Steroidogenic acute regulatory protein

\section{Funding}

This study was funded by the German research foundation.

\section{Availability of data and materials}

The data obtained from this study are available from the corresponding author on reasonable request.

\section{Authors' contributions}

HOP performed the cell culture, transfection, aRT-PCR, western blotting cell cycle and proliferation assay, data analysis, interpreting the results and drafting and writing the manuscript. DT conceived and designed the experiment, interpreted the results and revised the manuscript. $\mathrm{MH}$ designed the experiment and revised the manuscript critically. SG, EH and CN revised the manuscript critically. ET supported in statistical analysis revised the manuscript. KS conceived, designed and supervised the experiment, critically revised the manuscript. DSW designed and supervised the experiment, interpreted the results and critically revised the manuscript. All authors read and approved the final manuscript.

\section{Ethics approval and consent to participate}

This study was carried out using the bovine granulosa cells collected from ovaries obtained from slaughterhouse and no special approval of this experiment by the concerned body was required.

\section{Competing interests}

The authors declare that they have no competing interests.

\section{Publisher's Note}

Springer Nature remains neutral with regard to jurisdictional claims in published maps and institutional affiliations.

\section{Author details \\ 'Department of Animal Breeding and Husbandry, Institute of Animal Science, University of Bonn, Endenicher Allee 15, 53115 Bonn, Germany. ${ }^{2}$ Teaching and Research Station Frankenforst, Faculty of Agriculture, University of Bonn, Königswinter, Germany. ${ }^{3}$ Center of Integrated Dairy Research, University of Bonn, Bonn, Germany.}

Received: 8 December 2017 Accepted: 23 April 2018

Published online: 01 May 2018

\section{References}

1. Orisaka M, Tajima K, Tsang BK, Kotsuji F. Oocyte-granulosa-theca cell interactions during preantral follicular development. J Ovarian Res. 2009:2:9. https://doi.org/10.1186/1757-2215-2-9.
2. Driancourt MA. Regulation of ovarian follicular dynamics in farm animals. Implications for manipulation of reproduction. Theriogenology. 2001;55: 1211-39.

3. Robker RL, Richards JS. Hormone-induced proliferation and differentiation of granulosa cells: a coordinated balance of the cell cycle regulators cyclin D2 and p27Kip1. Mol Endocrinol. 1998;12:924-40.

4. Buccione R, Schroeder AC, Eppig JJ. Interactions between somatic cells and germ cells throughout mammalian oogenesis. Biol Reprod. 1990;43:543-7.

5. Toda K, Hayashi Y, Ono M, Saibara T. Impact of ovarian sex steroids on ovulation and ovulatory gene induction in aromatase-null mice. Endocrinology. 2012;153:386-94.

6. Richards JS. Hormonal control of gene expression in the ovary. Endocr Rev. 1994;15:725-51. https://doi.org/10.1210/edrv-15-6-725.

7. Huang Z, Wells D. The human oocyte and cumulus cells relationship: new insights from the cumulus cell transcriptome. Mol Hum Reprod. 2010;16: 715-25. https://doi.org/10.1093/molehr/gaq031.

8. Nivet A-L, Vigneault C, Blondin P, Sirard M-A. Changes in granulosa cells' gene expression associated with increased oocyte competence in bovine. Reproduction. 2013:145:555-65.

9. Douville G, Sirard M-A. Changes in granulosa cells gene expression associated with growth, plateau and atretic phases in medium bovine follicles. J Ovarian Res. 2014;7:50.

10. Bartel DP. MicroRNAs: Genomics, biogenesis, mechanism, and function. Cell. 2004;116:281-97.

11. Ambros V. The functions of animal microRNAs. Nature. 2004:431:350-5.

12. Andreas E, Hoelker M, Neuhoff C, Tholen E, Schellander K, Tesfaye D, Salilew-Wondim D. MicroRNA 17-92 cluster regulates proliferation and differentiation of bovine granulosa cells by targeting PTEN and BMPR2 genes. Cell Tissue Res. 2016;366:219-30.

13. Gebremedhn S, Salilew-Wondim D, Hoelker M, Rings F, Neuhoff C, Tholen E, et al. MicroRNA-183 96 182 cluster regulate bovine Granulosa cell proliferation and cell cycle transition by coordinately targeting FOXO1. Biol Reprod. 2016;94:127

14. Mani AM, Fenwick MA, Cheng Z, Sharma MK, Singh D, Wathes DC. IGF1 induces up-regulation of steroidogenic and apoptotic regulatory genes via activation of phosphatidylinositol-dependent kinase/AKT in bovine granulosa cells. Reproduction. 2010;139:139-51.

15. Evans ACO, Ireland JLH, Winn ME, Lonergan P, Smith GW, Coussens PM Ireland JJ. Identification of genes involved in apoptosis and dominant follicle development during follicular waves in cattle. Biol Reprod. 2004; 70:1475-84.

16. Myers M, van den Driesche $S, M c N e i l l y ~ A S$, Duncan WC. Activin a reduces luteinisation of human luteinised granulosa cells and has opposing effects to human chorionic gonadotropin in vitro. J Endocrinol. 2008;199:201-12.

17. Ali A, Lange A, Gilles M, Glatzel PS. Morphological and functional characteristics of the dominant follicle and corpus luteum in cattle and their influence on ovarian function. Theriogenology. 2001;56:569-76.

18. Manikkam M, Rajamahendran R. Progesterone-induced atresia of the proestrous dominant follicle in the bovine ovary: changes in diameter, insulin-like growth factor system, aromatase activity, steroid hormones, and apoptotic index. Biol Reprod. 1997:57:580-7.

19. Pollack SE, Furth EE, Kallen CB, Arakane F, Kiriakidou M, Kozarsky KF, Strauss JF. Localization of the steroidogenic acute regulatory protein in human tissues. J Clin Endocrinol Metab. 1997;82:4243-51.

20. McManus MT. MicroRNAs and cancer. Semin Cancer Biol. 2003:13:253-8.

21. Lee RC, Feinbaum RL, Ambros V. The C. Elegans heterochronic gene lin-4 encodes small RNAs with antisense complementarity to lin-14. Cell. 1993;75:843-54.

22. Carletti MZ, Fiedler SD, Christenson LK. MicroRNA 21 blocks apoptosis in mouse periovulatory granulosa cells. Biol Reprod. 2010;83:286-95.

23. Gebremedhn S, Salilew-Wondim D, Ahmad I, Sahadevan S, Hossain MM, Hoelker M, et al. MicroRNA expression profile in bovine Granulosa cells of Preovulatory dominant and subordinate follicles during the late follicular phase of the estrous cycle. PLoS One. 2015;10:e0125912.

24. Jiang L, Huang J, Li L, Chen Y, Chen X, Zhao X, Yang D. MicroRNA-93 promotes ovarian granulosa cells proliferation through targeting CDKN1A in polycystic ovarian syndrome. J Clin Endocrinol Metab. 2015;100:E729-38.

25. Sirotkin AV, Kisová G, Brenaut P, Ovcharenko D, Grossmann R, Mlyncek M. Involvement of microRNA Mir15a in control of human ovarian granulosa cell proliferation, apoptosis, steroidogenesis, and response to FSH. Microrna. 2014;3:29-36. 
26. Sirotkin AV, Lauková M, Ovcharenko D, Brenaut $P$, Mlyncek M. Identification of microRNAs controlling human ovarian cell proliferation and apoptosis. J Cell Physiol. 2010;223:49-56.

27. Sirotkin AV, Ovcharenko D, Grossmann R, Laukova M, Mlyncek M. Identification of microRNAs controlling human ovarian cell steroidogenesis via a genome-scale screen. J Cell Physiol. 2009;219:415-20.

28. Wu S, Sun H, Zhang Q, Jiang Y, Fang T, Cui l, et al. MicroRNA-132 promotes estradiol synthesis in ovarian granulosa cells via translational repression of Nurr1. Reprod Biol Endocrinol. 2015;13:94

29. Salilew-Wondim D, Ahmad I, Gebremedhn S, Sahadevan S, Hossain MD, Rings $F$, et al. The expression pattern of microRNAs in granulosa cells of subordinate and dominant follicles during the early luteal phase of the bovine estrous cycle. PLoS One. 2014;9:e106795.

30. Zhang D, Shi Z, Li M, Mi J. Hypoxia-induced miR-424 decreases tumor sensitivity to chemotherapy by inhibiting apoptosis. Cell Death Dis. 2014;5:e1301

31. Llobet-Navas D, Rodríguez-Barrueco R, Castro V, Ugalde AP, Sumazin P, Jacob-Sendler D, et al. The miR-424(322)/503 cluster orchestrates remodeling of the epithelium in the involuting mammary gland. Genes Dev. 2014;28:765-82

32. Xu S, Tao Z, Hai B, Liang H, Shi Y, Wang T, et al. miR-424(322) reverses chemoresistance via T-cell immune response activation by blocking the PDL1 immune checkpoint. Nat Commun. 2016;7:11406.

33. Knight PG, Glister C. TGF-beta superfamily members and ovarian follicle development. Reproduction. 2006;132:191-206.

34. Agarwal V, Bell GW, Nam J-W, Bartel DP. Predicting effective microRNA target sites in mammalian mRNAs. elife. 2015; https://doi.org/10.7554/eLife.05005.

35. Friedman RC, Farh KK-H, Burge CB, Bartel DP. Most mammalian mRNAs are conserved targets of microRNAs. Genome Res. 2009;19:92-105. https://doi. org/10.1101/gr.082701.108.

36. Li Q. Inhibitory SMADs: Potential regulators of ovarian function. Biol Reprod. 2015;92:50.

37. Matzuk MM, Kumar TR, Bradley A. Different phenotypes for mice deficient in either activins or activin receptor type II. Nature. 1995;374:356-60. https:// doi.org/10.1038/374356a0.

38. Livak KJ, Schmittgen TD. Analysis of relative gene expression data using real-time quantitative PCR and the 2(-Delta Delta C(T)) method. Methods. 2001:25:402-8

39. Bradford MM. A rapid and sensitive method for the quantitation of microgram quantities of protein utilizing the principle of protein-dye binding. Anal Biochem. 1976;72:248-54

40. Maalouf SW, Liu WS, Pate JL. MicroRNA in ovarian function. Cell Tissue Res. 2016:363:7-18

41. Zhang $Q$, Sun $H$, Jiang $Y$, Ding L, Wu S, Fang T, et al. MicroRNA-181a suppresses mouse granulosa cell proliferation by targeting activin receptor IIA. PLoS One. 2013:8:e59667

42. Liu J, Yao W, Yao Y, Du X, Zhou J, Ma B, et al. MiR-92a inhibits porcine ovarian granulosa cell apoptosis by targeting Smad7 gene. FEBS Lett. 2014; 588:4497-503.

43. Yan G, Zhang L, Fang T, Zhang Q, Wu S, Jiang Y, et al. MicroRNA-145 suppresses mouse granulosa cell proliferation by targeting activin receptor IB. FEBS Lett. 2012;586:3263-70

44. Abd El Naby WS, Hagos TH, Hossain MM, Salilew-Wondim D, Gad AY Rings $F$, et al. Expression analysis of regulatory microRNAs in bovine cumulus oocyte complex and preimplantation embryos. Zygote. 2013; 21:31-51.

45. Gao Y, Wen H, Wang C, Li Q. SMAD7 antagonizes key TGFß superfamily signaling in mouse granulosa cells in vitro. Reproduction. 2013;146:1-11.

46. Yin M, Lü M, Yao G, Tian H, Lian J, Liu L, et al. Transactivation of microRNA-383 by steroidogenic factor-1 promotes estradiol release from mouse ovarian granulosa cells by targeting RBMS1. Mol Endocrinol. 2012;26:1129-43.

47. Yao G, Yin M, Lian J, Tian H, Liu L, Li X, Sun F. MicroRNA-224 is involved in transforming growth factor-beta-mediated mouse granulosa cell proliferation and granulosa cell function by targeting Smad4. Mol Endocrinol. 2010;24:540-51.

48. Liu M, Liu P, Zhang L, Cai Q, Gao G, Zhang W, et al. Mir-35 is involved in intestine cell G1/S transition and germ cell proliferation in C. Elegans. Cell Res. 2011;21:1605-18.

49. Maruo T. Expression of oncogenes, growth factors and their receptors in follicular growth, regression and atresia: their roles in granulosa cell proliferation and differentiation. Nihon Sanka Fujinka Gakkai Zasshi. 1995;47: 738-50.

50. Lucy MC, Thatcher WW, MacMillan KL. Ultrasonic identification of follicular populations and return to estrus in early postpartum dairy cows given intravaginal progesterone for 15 days. Theriogenology. 1990;34:325-40.

51. Sirois J, Fortune JE. Lengthening the bovine estrous cycle with low levels of exogenous progesterone: a model for studying ovarian follicular dominance. Endocrinology. 1990;127:916-25.

52. Savio JD, Thatcher WW, Badinga $L$, de la Sota RL, Wolfenson D. Regulation of dominant follicle turnover during the oestrous cycle in cows. J Reprod Fertil. 1993:97:197-203.

53. Wang S, Liu J, Li X, Ji X, Zhang J, Wang Y, Cui S. MiR-125b regulates primordial follicle assembly by targeting Activin receptor type 2a in neonatal mouse ovary. Biol Reprod. 2016;94:83.

54. Cheng J-C, Chang H-M, Qiu X, Fang L, Leung PCK. FOXL2-induced follistatin attenuates activin A-stimulated cell proliferation in human granulosa cell tumors. Biochem Biophys Res Commun. 2014;443:537-42.

55. Chang H-M, Cheng J-C, Huang H-F, Shi F-T, Leung PCK. Activin a, B and AB decrease progesterone production by down-regulating StAR in human granulosa cells. Mol Cell Endocrinol. 2015;412:290-301.

56. Knight $P G$, Satchell $L$, Glister C. Intra-ovarian roles of activins and inhibins. Mol Cell Endocrinol. 2012;359:53-65.

57. Tsuchida K, Nakatani M, Uezumi A, Murakami T, Cui X. Signal transduction pathway through activin receptors as a therapeutic target of musculoskeletal diseases and cancer. Endocr J. 2008;55:11-21.

58. Blahna MT, Hata A. Smad-mediated regulation of microRNA biosynthesis. FEBS Lett. 2012;586:1906-12.

59. Kato M, Putta S, Wang M, Yuan H, Lanting L, Nair I, et al. TGF-beta activates Akt kinase through a microRNA-dependent amplifying circuit targeting PTEN. Nat Cell Biol. 2009;11:881-9.

60. Sun Q, Zhang Y, Yang G, Chen X, Zhang Y, Cao G, et al. Transforming growth factor-beta-regulated miR-24 promotes skeletal muscle differentiation. Nucleic Acids Res. 2008:36:2690-9.

61. Findlay JK, Drummond AE, Britt KL, Dyson M, Wreford NG, Robertson DM, et al. The roles of activins, inhibins and estrogen in early committed follicles. Mol Cell Endocrinol. 2000;163:81-7.

62. Knight $P G$. Roles of inhibins, activins, and follistatin in the female reproductive system. Front Neuroendocrinol. 1996;17:476-509.

63. Knight $\mathrm{PG}$, Glister $\mathrm{C}$. Potential local regulatory functions of inhibins, activins and follistatin in the ovary. Reproduction. 2001;121:503-12.

64. Erickson GF, Magoffin DA, Garzo VG, Cheung AP, Chang RJ. Granulosa cells of polycystic ovaries: are they normal or abnormal? Hum Reprod. 1992;7: 293-9.

65. Willis DS, Watson H, Mason HD, Galea R, Brincat M, Franks S. Premature response to luteinizing hormone of granulosa cells from anovulatory women with polycystic ovary syndrome: relevance to mechanism of anovulation. J Clin Endocrinol Metab. 1998;83:3984-91.

66. Jakimiuk AJ, Weitsman SR, Navab A, Magoffin DA. Luteinizing hormone receptor, steroidogenesis acute regulatory protein, and steroidogenic enzyme messenger ribonucleic acids are overexpressed in thecal and granulosa cells from polycystic ovaries. J Clin Endocrinol Metab. 2001;86:1318-23.

67. Malmstrom H, Hogberg T, Risberg B, Simonsen E. Granulosa cell tumors of the ovary: prognostic factors and outcome. Gynecol Oncol. 1994;52:50-5.

68. Wu K, Hu G, He X, Zhou P, Li J, He B, Sun W. MicroRNA-424-5p suppresses the expression of SOCS6 in pancreatic cancer. Pathol Oncol Res. 2013;19: 739-48.

\section{Ready to submit your research? Choose BMC and benefit from}

- fast, convenient online submission

- thorough peer review by experienced researchers in your field

- rapid publication on acceptance

- support for research data, including large and complex data types

- gold Open Access which fosters wider collaboration and increased citations

- maximum visibility for your research: over $100 \mathrm{M}$ website views per year

At BMC, research is always in progress.

Learn more biomedcentral.com/submissions 